\title{
Birt-Hogg-Dubé syndrome
}

\section{Zespół Birta-Hogg-Dubégo}

\author{
Bartosz Ptak, Grażyna Wąsik \\ General and Oncological Dermatology, Provincial Hospital, Opole, Poland \\ Oddział Dermatologii Ogólnej i Onkologicznej, Szpital Wojewódzki, Opole, Polska
}

Dermatol Rev/Przegl Dermatol 202।, I08, 285-289

DOI: https://doi.org/| 0.5 | |4/dr.2021 . I 10784

\author{
CORRESPONDING AUTHOR/ \\ ADRES DO KORESPONDENCJI: \\ lek. Bartosz Ptak \\ Oddział Dermatologii \\ Ogólnej i Onkologicznej \\ Szpital Wojewódzki \\ Opole, Polska \\ e-mail: bartoszptak2301@gmail.com
}

\begin{abstract}
Introduction: Birt-Hogg-Dubé syndrome is a rare genodermatosis inherited as an autosomal dominant trait. Birt-Hogg-Dubé syndrome was first described in 1977 by three dermatologists, Arthur Birt, Georgina Hogg and William J. Dubé. It is characterised by the development of multiple small white bumps primarily occurring on the face and chest. Birt-Hogg-Dubé syndrome is associate with an increased risk or pneumothorax, pulmonary cysts, and renal tumours. The disorder is caused by mutations in the FLCN gene, which encodes folliculin.
\end{abstract}

Cas report: A 50-year-old man presented with multiple yellowish-white papules located on cheeks and forehead. Earlier the patient was hospitalized because of pneumothorax. Diagnostic imaging revealed pulmonary cysts and fibrosis, most likely secondary to previous pneumothorax. Abdominal ultrasound showed no tumours. The diagnosis of Birt-Hogg-Dubé syndrome was established on the basis of clinical evaluation and confirmed by genetic testing.

Conclusions: The treatment of fibrofolliculomas in the course of Birt-Hogg-Dubé syndrome usually involves ablative laser therapy. The prognosis is good, although it depends on the patient's general health, especially the severity of respiratory failure and the presence of renal malignancy. Patients with Birt-Hogg-Dubé syndrome require regular follow-up for pulmonary changes and renal tumors.

Key words: Birt-Hogg-Dubé syndrome, fibrofolliculoma, pneumothorax, renal tumours.

\section{STRESZCZENIE}

Wprowadzenie: Zespół Birta-Hogg-Dubégo jest rzadką genodermatozą o dziedziczeniu autosomalnym dominującym. Został opisany po raz pierwszy w 1977 roku przez trzech dermatologów Artura Birta, Georginę Hogg i Williama J. Dubégo. Charakteryzuje się rozwojem licznych, drobnych, białych grudek zlokalizowanych głównie w obrębie twarzy i górnej części tułowia. Predysponuje ponadto do rozwoju odmy opłucnowej, torbieli płuc i nowotworowych guzów nerek. Jest on wywołany mutacjami w genie FLCN kodującym folikulinę.

Opis przypadku: Mężczyzna, lat 50, zgłosił się z bardzo licznymi białożółtymi grudkami zlokalizowanymi na policzkach i czole. W tym samym roku pacjent był hospitalizowany na oddziale pulmonologii 
z powodu odmy opłucnowej. W badaniach obrazowych wykazano obecność torbieli w płucach oraz zwłóknień najprawdopodobniej po wcześniej przebytych odmach. W badaniu ultrasonograficznym jamy brzusznej nie stwierdzono zmian nowotworowych. Na podstawie obrazu klinicznego i wyników badan dodatkowych, w tym genetycznych, ustalono rozpoznanie zespołu Birta-Hogg-Dubégo.

Wnioski: Leczenie zmian skórnych typu fibrofolliculoma polega najczęściej na laseroterapii laserami ablacyjnymi. Rokowanie określa się jako stosunkowo dobre, zależne od ogólnego stanu zdrowia, w szczególności wydolności oddechowej i rozwoju złośliwych guzów nerek. Pacjenci wymagają regularnych badań kontrolnych w celu wczesnego wykrycia zmian w układzie oddechowym i nerkach.

Słowa kluczowe: zespół Birta-Hogg-Dubégo, fibrofolliculoma, odma opłucnowa, nowotwory nerek.

\section{INTRODUCTION}

Birt-Hogg-Dubé syndrome (BHDS) is a rare genodermatosis inherited as an autosomal dominant trait. It is characterised by the development of hundreds of small white bumps primarily occurring on the face and upper torso. The lesions originate from hair follicle cells and correspond to benign fibrofolliculomas. BHDS predisposes to pneumothorax, pulmonary cysts, and renal tumours. The disorder is caused by FLCN mutations at the 17p11.2 locus encoding folliculin.

\section{OBJECTIVE}

We present a case of BHDS, a rare genodermatosis, and a literature review.

\section{CASE REPORT}

A 50-year-old man with previously undiagnosed, multiple yellowish-white papules located symmetrically on both cheeks (fig. 1) reported to the clinic. The first papules had occurred when the patient was

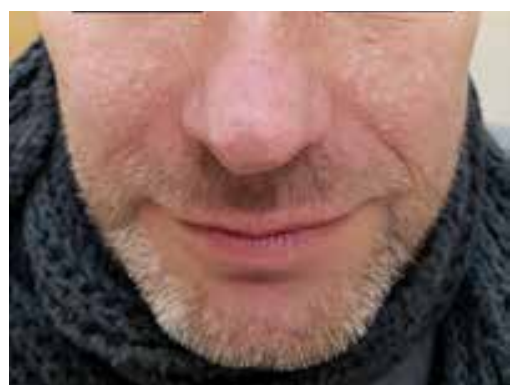

Figure I. Patient with Birt-Hogg-Dubé syndrome Rycina I. Pacjent z zespołem Birta-Hogg-Dubégo

\section{WPROWADZENIE}

Zespół Birta-Hogg-Dubégo (Birt-Hogg-Dubé syndrome - BHDS) jest rzadką genodermatozą o dziedziczeniu autosomalnym dominującym. Charakteryzuje się występowaniem kilkuset drobnych białych grudek umiejscowionych głównie w obrębie twarzy i górnej części tułowia. Zmiany wywodzą się z komórek mieszka włosowego i są łagodnymi guzami typu fibrofolliculoma. BHDS predysponuje ponadto do rozwoju odmy opłucnowej, torbieli płuc i nowotworowych guzów nerek. Zespół jest wywołany mutacjami w genie FLCN w locus 17p11.2 kodującym folikulinę.

\section{CEL PRACY}

Celem pracy jest przedstawienie przypadku rzadkiej genodermatozy, jaką jest BHDS, oraz przegląd piśmiennictwa dotyczącego tego zagadnienia.

\section{OPIS PRZYPADKU}

Do poradni zgłosił się 50-letni pacjent $\mathrm{z}$ dotychczas niezdiagnozowanymi, bardzo licznymi białożółtymi grudkami zlokalizowanymi symetrycznie na obu policzkach oraz czole (ryc. 1). Pierwsze grudki zaczęły się pojawiać około 20. roku życia, a wraz z wiekiem stopniowo liczba zmian zwiększała się. Błona śluzowa jamy ustnej była wolna od zmian. W tym samym roku pacjent był hospitalizowany na oddziale pulmonologii z powodu odmy opłucnowej. W badaniach obrazowych wykazano obecność torbieli w płucach oraz zwłoknień najprawdopodobniej po wcześniej przebytych odmach. W badaniu ultrasonograficznym jamy brzusznej nie stwierdzono guzów nowotworowych. Pacjent podawał występowanie 
about 20 years old, and their number gradually increased with age. There was no involvement of oral mucosa. In the same year, the patient was hospitalised in the Department of Pulmonology due to pneumothorax. Diagnostic imaging performed at that time revealed pulmonary cysts and fibrosis, most likely secondary to previous pneumothorax. Abdominal ultrasound showed no tumours. The patient reported family history of similar lesions in his grandfather, father, and father's sister, who also developed recurrent pneumothorax. He also reported malignant tumours in his father's family members, but it was not possible to confirm whether these were renal tumours. The diagnostic workup involved a genetic test in a nephew with single lesions in the form of white facial papules, showing a mutation in the FLCN gene at the 17p11 locus, which ultimately confirmed the diagnosis, also in the described patient.

\section{DISCUSSION}

BHDS was first described in 1977 by three dermatologists, Arthur Birt, Georgina Hogg and William J. Dubé $[1,2]$. It is a rare genodermatosis inherited as an autosomal dominant trait, with equal male-to-female ratio. The disorder is usually diagnosed in the fourth or fifth decade of life [3].

BHDS is caused by FLCN mutations at the 17p11.2 locus encoding folliculin [3, 4]. To date, more than 150 mutations of this gene have been identified, the majority of which occur in approximately $44 \%$ of families [2]. Under normal conditions, this gene belongs to the family of suppressor genes [3,5]. Folliculin, which is its product, interacts with mTOR and MAPK kinases, plakophilin 4 (PKP4) and cadherin E5,6, thereby preventing neoplastic transformation $[2,4]$. Folliculin is also responsible for the mechanisms of cellular adhesion and proper functioning of intercellular connections $[2,4]$.

Patients with BHDS develop skin lesions in the form of hundreds of fine perifollicular papules [1]. These skin lesions are the most common symptom found in up to $85 \%$ of patients $[1,6,7]$. The lesions are mainly located on the scalp, face, and chest, although they can also appear around the auricles and mouth $[1,7]$. The lesions are about $2-3 \mathrm{~mm}$ in size, dome-shaped and white-yellow or in the colour of unaffected skin. The number of lesions in individual family members who may have the same FLCN mutation may vary from several up to several hundred. The lesions produce no subjective symptoms [1]. The onset of skin lesions is observed at about 20 years of age $[1,2]$.

The perifollicular papules derive from the cells of the hair follicle [8]. The process involves proliferation of the perifollicular mesenchyme, possibly derived podobnych zmian u dziadka, ojca oraz siostry ojca. Jednocześnie u tych samych osób występowały nawracające odmy opłucnowe. Ponadto u członków rodziny ze strony ojca pojawiały się guzy nowotworowe, bez możliwości określenia ich typu przez pacjenta. W diagnostyce wykonano badanie genetyczne u siostrzeńca pacjenta, u którego występowały pojedyncze białe grudki na twarzy. Wykazano mutację w genie FLCN $\mathrm{w}$ locus $17 \mathrm{p} 11$, co potwierdziło rozpoznanie $\mathrm{u}$ przedstawionego pacjenta.

\section{OMÓWIENIE}

BHDS opisało po raz pierwszy w 1977 roku trzech dermatologów: Artur Birt, Georgina Hogg i Wiliam J. Dubé [1, 2]. Jest rzadką genodermatozą o dziedziczeniu autosomalnym dominującym. Zarówno kobiety, jak i mężczyźni chorują w równych proporcjach. Choroba rozpoznawana jest zazwyczaj w czwartej lub piątej dekadzie życia [3].

BHDS jest wywołany mutacjami w genie FLCN w locus 17p11.2 kodującym folikulinę [3, 4]. Zidentyfikowano dotychczas ponad 150 mutacji tego genu, najczęstsza $\mathrm{z}$ nich występuje $\mathrm{u}$ około $44 \%$ rodzin [2]. Gen ten należy do rodziny genów supresorowych $[3,5]$. Folikulina będąca jego produktem w wyniku interakcji z kinazami mTOR oraz MAPK, plakofiliną 4 (PKP4) i kadheryną E5,6 przeciwdziała transformacji nowotworowej $[2,4]$. Folikulina odpowiada również za mechanizmy adhezji komórkowej i właściwe funkcjonowanie połączeń międzykomórkowych $[2,4]$.

W BHDS zmiany skórne występują w postaci kilkuset drobnych wokółmieszkowych grudek [1]. Grudki skórne są najczęstszym objawem występującym nawet u $85 \%$ pacjentów [1, 6, 7]. Zmiany lokalizują się głównie w obrębie owłosionej skóry głowy, twarzy i klatki piersiowej, ale mogą również występować w obrębie małżowin usznych i jamy ustnej $[1,7]$. Poszczególne wykwity osiągają wymiar około 2-3 mm, mają kopulasty kształt i są barwy białożółtej lub mają kolor zdrowej skóry. Liczba grudek u poszczególnych członków rodziny mogących mieć tę samą mutację FLCN może być zróżnicowana od kilku do nawet kilkuset. Zmianom skórnym nie towarzyszą objawy subiektywne [1]. Początek rozwoju zmian skórnych przypada na około 20. rok życia [1, 2].

Wokółmieszkowe grudki wywodzą się z komórek mieszka włosowego [8]. Zmiany przebiegają z proliferacją okołomieszkowej mezenchymy, prawdopodobnie związanej z osłonką mieszka. W przebiegu BHDS opisuje się również zmiany typu trichodiscoma. Niektórzy autorzy są zdania, że trichodiscoma i fibrofolliculoma to te same zmiany w różnych stadiach rozwoju bądź zaniku. W zależności od fazy rozwoju wykwitu obraz histopatologiczny może być odmiennie interpretowany [2, 9]. BHDS charakte- 
from the sheath of the follicle. Trichodiscomas have also been described in BHDS. Some authors are of the opinion that these lesions correspond to fibrofolliculomas, but at different stages of development or involution. Consequently, depending on the stage of lesion development, the histopathological picture may be interpreted differently $[2,9]$. BHDF is characterised by an increased incidence of soft fibromas. Among the approximately 600 families with BHDS presented so far, more frequent occurrence of oral lumps, lipomas, angiomyolipomas, tumours of the parathyroid glands or salivary glands, and nevi arising from connective tissue have also been reported.

Although pneumothorax usually develops at 30-40 years of age, it has been reported even in 7-year-olds. FLCN mutation is associated with 50 -fold increased risk of pneumothorax compared to the general population [2]. Furthermore, pulmonary cysts, usually asymptomatic, may develop in up to $80 \%$ of patients [5]. Kidney cancer most often develops between the ages of 40 and 50 years [6]. Renal tumours are often bilateral and multifocal. They may be benign or malignant $[6,10]$. The most common tumours include hybrid oncocytic/chromophobe tumour (HOCT) and chromophobe tumour, both of which are malignant $[6,9]$. Benign oncocytoma is rare [8]. It is estimated that multiple renal tumours occur in 15-30\% of patients with BHD [9]. FLCN mutation is associated with about 7-fold increase in the risk of renal tumours [9].

BHDS is diagnosed based on the characteristic triad of symptoms: benign skin lesions arising from hair follicles with at least two fibrofolliculomas (85\%), family history of recurrent pneumothorax with/or pulmonary cysts $(80 \%)$, as well as benign and malignant renal tumours $(15-30 \%)[4,7,9]$. The diagnosis is confirmed by a mutation detected in the FLCN gene at the $17 \mathrm{p} 11.2$ locus encoding folliculin $[1,2]$. Some authors recommend performing genetic tests from the age of 21 years in patients with a family history of BHDS [9].

Due to the increased risk of developing malignant kidney tumours, annual abdominal imaging is recommended. Computed tomography is recommended for the imaging of pulmonary cysts and pneumothorax $[5,7]$. It shows the presence of cysts of various shapes and sizes, with well-defined walls and a diameter ranging from several millimetres to several centimetres $[6,7,11]$ Standard radiology usually fails to visualise the lesions $[5,11]$.

The treatment of fibrofolliculomas usually involves ablative laser therapy. Despite the high efficacy of this treatment, the lesions tend to recur [2]. However, the prognosis is good, although it depends on the patient's health, the severity of respiratory failure and the presence of renal malignancy [10]. Treatment with mTOR inhibitors has been successfully attempted in patients with progressive renal cancer [9]. ryzuje sie częstszym występowaniem włókniaków miękkich. Wśród dotychczas przedstawionych około 600 rodzin z BHDS opisywano również częstsze pojawianie się grudek w obrębie jamy ustnej, tłuszczaków, naczyniakotłuszczaków, guzów przytarczyc i ślinianek oraz znamion wywodzących się z tkanki łącznej.

Rozwój odm opłucnowych przypada zwykle na 30.-40. rok życia, lecz opisywano ich występowanie już nawet u 7-latków. Obecność mutacji FLCN zwiększa 50-krotnie ryzyko rozwoju odmy opłucnowej [2]. W płucach występują dodatkowo bezobjawowe torbiele u około $80 \%$ pacjentów [5]. Do zachorowania na nowotwory nerki dochodzi najczęściej między 4. i 5. dekadą życia [6]. Guzy nerek zarówno łagodne, jak i złośliwe występują często obustronie oraz wieloogniskowo [6, 10]. Do najczęściej stwierdzanych guzów należą: hybrydowy guz typu onkocytoma/ rak chromofobowy oraz rak chromofobowy[6, 9]. Łagodny guz typu onkocytoma pojawia się rzadko [8]. Występowanie mnogich guzów nerek u pacjentów z BHDS szacuje się na 15-30\% [9]. Mutacja FLCN zwiększa około 7-krotnie ryzyko rozwoju nowotworów nerek [9].

Rozpoznanie BHDS ustala się na podstawie charakterystycznej triady następujących objawów: łagodne rozrosty wywodzące się z mieszków włosowych, w tym co najmniej dwa fibrofolliculoma (85\%), rodzinnie występujące epizody nawracających odm opłucnowych z/lub obecnością torbieli w płucach $(80 \%)$ oraz występowanie łagodnych i złośliwych nowotworowych guzów nerek (15-30\%) [4, 7, 9]. Potwierdzenie rozpoznania polega na wykryciu mutacji w genie FLCN w locus 17p11.2 kodującym folikulinę [1, 2]. Część autorów rekomenduje wykonywanie testów genetycznych od 21. roku życia u pacjentów z obciążającym wywiadem rodzinnym [9].

W związku z podwyższonym ryzykiem rozwoju nowotworowych guzów nerek zaleca się wykonywanie corocznych badań obrazowych jamy brzusznej. Do zobrazowania torbieli płuc, odm opłucnowych zaleca się wykonanie tomografii komputerowej $[5,7]$. Badanie to wykazuje obecność różnokształtnych cyst lub torbieli o dobrze widocznych ścianach i średnicy od kilku milimetrów do kilku centymetrów $[6,7,11]$. Standardowe badanie radiologiczne najczęściej nie pozwala na zobrazowanie zmian $[5,11]$.

Leczenie zmian skórnych typu fibrofolliculoma polega najczęściej na ich laseroterapii laserami ablacyjnymi. Terapia jest wysoce skuteczna, jednak zmiany mają tendencję do nawrotów [2]. Rokowanie jest dobre. Zależy jednak od aktualnego stanu zdrowia, stopnia niewydolności oddechowej oraz obecności złośliwych guzów nerek [10]. U pacjentów z progre- 


\section{CONCLUSIONS}

BHDS is a rare genodermatosis with typical cutaneous and extracutaneous manifestations. The diagnosis of the syndrome is important as it enables preventing potentially life-threatening malignant lesions and pleural involvement.

\section{CONFLICT OF INTEREST}

The authors declare no conflict of interest. sją raka nerki podejmowano skuteczne próby leczenia inhibitorami mTOR [9].

\section{WNIOSKI}

BHDS jest rzadko występującą genodermatozą o charakterystycznych objawach skórnych i pozaskórnych. Rozpoznanie zespołu jest istotne ze względu na możliwość profilaktyki potencjalnie zagrażających życiu złośliwych zmian nowotworowych oraz odm opłucnowych.

\section{KONFLIKT INTERESÓW}

Autorzy nie zgłaszają konfliktu interesów.

\section{References}

\section{Piśmiennictwo}

1. Radzikowska E.: Torbielowate choroby płuc - postępy diagnostyki i leczenia. Część druga. Med Dypl 2020, 1, 16-17.

2. Menko F.H., van Steensel M.A., Giraud S., Friis-Hansen L., Richard S., Ungari S., et al.: Birt-Hogg-Dubé syndrome: diagnosis and management. Lancet Oncol 2009, 10, 1199-1206.

3. Kumasaka T., Hayashi T., Mitani K., Kataoka H., Kikkawa M., Tobino K., et al.: Characterization of pulmonary cysts in Birt-Hogg-Dube syndrome: histopathological and morphometric analysis of 229 pulmonary cysts from 50 unrelated patients. Histopathology 2014, 65, 100-110.

4. Schmidt L.S., Linehan W.M.: Molecular genetics and clinical features of Birt-Hogg-Dube'-syndrome. Nat Rev Urol 2015, 12, 558.

5. Gupta N., Kopras E.J., Henske E.P., James L.E., El-Chemaly S., Veeraraghavan S., et al.: Spontaneous pneumothoraces in patients with Birt-Hogg-Dubé syndrome. Ann Am Thorac Soc 2017, 14, 706-713.

6. Stamatakis L., Metwalli A.R., Middelton L.A., Linehan W.M.: Diagnosis and management of BHD-associated kidney cancer. Fam Cancer 2013, 12, 397-402.

7. Vernooij M., Claessens T., Luijten M., van Steensel M.A., Coull B.J.: Birt-Hogg-Dubé syndrome and the skin. Fam Cancer $2013,12,381-385$

8. Seo M., Lim D.H., Song J.S., Park C.S., Chae E.J., Song J.W., et al.: Two cases of Birt-Hogg-Dube syndrome with pulmonary cysts. Korean J Med 2014, 87, 477-483.

9. Schmidt L.S., Linehan W.M.: FLCN: the causative gene for Birt-Hogg-Dubé syndrome. Gene 2018, 640, $28-42$.

10. Stamatakis L., Metwalli A.R., Middelton L.A., Linehan W.M.: Diagnosis and management of BHD-associate kidney cancer. Fam Cancer 2013, 12, 397-402.

11. Radzikowska E., Barańska I., Sobczyńska-Tomaszewska A., Wiatr E., Roszkowski-Śliż K.: Familial pneumpothoraces: Birt-Hogg-Dube syndrome. Pol Arch Med Wewn 2016, 126, 897-898.

Received: 21.07 .2021

Accepted: 5.09 .2021

Otrzymano: 21.07.2021 r

Zaakceptowano: $5.09 .2021 \mathrm{r}$.

How to cite this article

Ptak B., Wąsik G.: Birt-Hogg-Dubé syndrome. Dermatol Rev/Przegl Dermatol 2021, 108, 285-289.

DOI: https://doi.org/10.5114/dr.2021.110784 